\title{
Effects of Shipping-originated Aerosols on Physical Cloud Properties over Marine Areas near East China
}

\author{
Xin Xie ${ }^{1}$, Xianming Zhang ${ }^{2}$, Yanyu Wang ${ }^{1}$, Rui Lyu ${ }^{1}$, Guangqiang Zhou ${ }^{3,4^{*}}$, Tiantao Cheng ${ }^{5,1^{*}}$, \\ Yuehui Liu', Yarong Peng ${ }^{1}$, Qianshan He ${ }^{3,4}$, Wei Gao ${ }^{3,4}$, Xiang Li ${ }^{1}$, Qian Zhang ${ }^{2}$ \\ ${ }^{1}$ Department of Environmental Science and Engineering, Institute of Atmospheric Sciences, Fudan University, Shanghai \\ 200433, China \\ ${ }^{2}$ Wireless Product R\&D Institute, ZTE Corporation, Shenzhen 518057, China \\ ${ }^{3}$ Shanghai Meteorological Service, Shanghai 20030, China \\ ${ }^{4}$ Shanghai Key Laboratory of Meteorology and Health, Shanghai 20030, China \\ ${ }^{5}$ Department of Atmospheric and Oceanic Sciences, Institute of Atmospheric Sciences, Fudan University, Shanghai \\ 200438, China
}

\begin{abstract}
Shipping emissions have received increasing attention due to their influence on regional climate, and air quality at ports and in coastal areas around the world. In the context of climatology, the effects of shipping-originated aerosols (using the

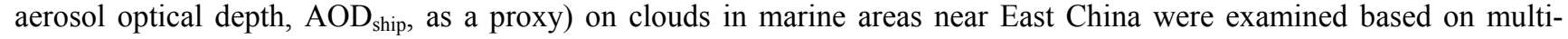
satellite datasets. On average, $\mathrm{AOD}_{\text {ship }}$ is approximately $0.17,0.20,0.15$ and 0.13 in the different seasons, contributing $23 \%, 30 \%, 36 \%$ and $25 \%$ of the total AOD, respectively. In remote sea areas, AOD $_{\text {ship }}$ is generally higher in spring and summer and lower in autumn. Statistical analysis shows that it is strongly related to the cloud parameters, such as the cloud fraction (CF), cloud optical thickness (COT) and cloud effective radius (CER) in the liquid phase. In particular, CER and $\mathrm{AOD}_{\text {ship }}$ exhibit a positive correlation in winter but a weakly negative correlation in summer over the northern East China Sea and a positive correlation in spring and summer over the Yellow Sea. In all four seasons, COT and CF decrease as $\mathrm{AOD}_{\text {ship }}$ increases. The correlations between $\mathrm{AOD}_{\text {ship }}$ and the cloud properties are stronger $(\mathrm{R}>0.3)$ when the aerosolcloud layers are well mixed than when they are separated, indicating that shipping-originated aerosols drawn into the cloud body can directly affect the microphysical properties of cloud droplets during cloud formation. The water vapor content and upward air motion are key thermodynamic conditions within the low atmospheric layers under the cloud bottom that play an important role in cloud formation and development. Our results provide new insight into the influence of shipping emissions on clouds in Asian marine areas.
\end{abstract}

Keywords: Shipping emissions; Aerosol; Cloud property; East China.

\section{INTRODUCTION}

Aerosols' direct and indirect effects can disturb the earth's climate system (IPCC, 2014). The effects of aerosols on clouds has become the largest uncertainty in assessing the anthropogenic aerosols' contribution to global climate change (Twomey, 1974; Rosenfeld, 2000; Kaufman et al., 2012; Gryspeerdt et al., 2014). As some aerosols act as cloud condensation nuclei $(\mathrm{CCN})$, an increase in particles entrained into clouds can lead to more and smaller cloud

\footnotetext{
* Corresponding authors.

Tel.: (86) 21-6564 3230; Fax: (86) 21-6564 2080

E-mail address: zhougq21@163.com (G. Zhou); ttcheng@fudan.edu.cn (T. Cheng)
}

droplets under constant liquid water path (Twomey, 1977) and then result in cloud albedo growth (Twomey, 1977). Meanwhile, the decrease of cloud droplet size causing clouds living longer with more pollution can impact precipitation cycles (Albrecht, 1989). Additionally, a possible reduction in precipitation frequency of liquid clouds through the suppression of drizzling prolongs the cloud lifetime (Albrecht, 1989).

Marine transportation has been viewed as one of the largest, least regulated sources of anthropogenic pollutants over oceans and coastal areas (Marmer and Langmann, 2005). Ships usually release massive amounts of primary pollutants, such as particles, $\mathrm{NO}_{2}, \mathrm{CO}, \mathrm{NMVOCs}$ and $\mathrm{SO}_{2}$, which results in significant local and spatial air pollution in ports and harbors, as well as secondary particles (e.g., secondary organic aerosol (SOA)) that are potentially harmful to human health (Saxe and Larsen, 2004). The 
ship exhaust amounts approximately $400 \mathrm{~km}$ within the coastline of the Yangtze River Delta (YRD) bordering the East China Sea were estimated to be approximately $3.8 \times$ $10^{5}, 7.1 \times 10^{5}$ and $5.1 \times 10^{4}$ ton $\mathrm{y}^{-1}$ annually for $\mathrm{SO}_{2}, \mathrm{NO}_{x}$ and $\mathrm{PM}_{2.5}$, respectively (Fan et al., 2016). Shipping emissions are a main contributor to $\mathrm{NO}_{2}$ and $\mathrm{SO}_{2}$ over many marine areas of the world, accounting for $0.5-5 \%$ of all $\mathrm{NO}_{2}$ and $\mathrm{SO}_{2}$ emissions at most ports and, in some ports, exceeding 10\% (Dalsøren et al., 2009). Furthermore, $11 \%$ of nitrate wet deposition and $4.5 \%$ of sulfur wet deposition globally result from shipping emissions, whereas in certain coastal regions up to $15-50 \%$ of nitrate and sulfur wet deposition result from shipping emissions (Dalsøren et al., 2009).

The influence of rising shipping pollution on clouds and precipitation has gradually become an open question (Rosenfeld et al., 2008; Stevens and Feingold, 2009). In recent years, some studies have explored the effect of shipping-originated aerosols on marine clouds (Petzold et al., 2008, 2010; Coggon et al., 2012; Juwono et al., 2013; Russell et al., 2013). Even low concentrations of larger CCN originated from ships can decrease cloud albedo by enhancing collision-coalescence, as proposed by Feingold et al. (1999). Wang et al. (2014a) figured out the effects of emissions from shipping on stratocumulus cloud water elemental composition during the 2011 E-PEACE field campaign. Chen et al. (2012) found occurrence of lower cloud albedo in ship tracks. The droplet sizes in clouds over ship tracks decrease and the total number of cloud droplets substantially increase compared to those in adjacent clouds, as observed by Radke et al. (1989). Sorooshian et al. (2015) found that aerosol particle concentrations behind ship tracks exceed those specified in the North American Emission Control Area (ECA; a sulfur content of marine fuel of no more than $1 \%$ ), and their number enhancement ratios decrease with growing downwind distance and altitude. Cloud droplet number has been reported to increase with aerosol loading over the East China Sea (Bennartz et al., 2011). Significant negative correlation coefficients were found between aerosol optical depth (AOD) and cloud effective radius (CER) for lower AOD levels over the East China Sea (Tang et al., 2014); meanwhile, positive correlations exist for higher AOD levels. In contrast, significant positive correlations exist over the Yellow Sea (YS) between the Korean Peninsula and Chinese mainland.

Container throughput is an important indicator to reflect the competitiveness of the shipping industry. By the end of 2016, there were 170 ultra-large ships with over 10,000 TEU on daily Asia-Europe routes, accounting for $43 \%$ of total ships (Tan, 2017). The East China region has densely clustered ports, and 4 of the top 10 ports in the world are located there, including the ports of Shanghai, NingboZhoushan, Qingdao and Suzhou. Meanwhile, the cargo throughput of these ports has experienced a rapid increase in recent years. To date, few studies have focused on the effect of aerosols from shipping-originated emissions on local air quality and regional climate over marine areas near East China.

In this study, the effect of shipping-originated aerosols on clouds over marine areas near East China was examined on the basis of multi-satellite data. The purpose is to exhibit the spatial distribution and seasonality of shippingoriginated aerosol optical depth $\left(\mathrm{AOD}_{\text {ship }}\right)$ over the focused domain and to evaluate the relationships between $\mathrm{AOD}_{\text {ship }}$ and main macro- and micro-scale cloud physical properties. Moreover, the relevant factors to influence the above correlations were also analyzed, including aerosolcloud mixture and meteorological conditions within low atmospheric layers.

\section{DATA AND METHODOLOGY}

\section{Study Area}

Fig. 1(a) shows the focused domain covering the northern areas of the East China Sea (NECS) and most areas of the Yellow Sea near East China, with an extent of $28-36.5^{\circ} \mathrm{N}$ and $121-128.5^{\circ}$ E. Fig. 1(b) shows the spatial distribution of annual mean primary $\mathrm{PM}_{2.5}$ from shipping emissions in 2014 (Chen et al., 2017). In 2014, the estimated shipping emissions of $\mathrm{PM}_{2.5}$ in the YRD region (latitude: $28-33.5^{\circ} \mathrm{N}$, longitude: $119.5-124^{\circ} \mathrm{E}$ ) were $4.91 \times 10^{4} \mathrm{t}$, accounting for $28-30 \%$ of the total shipping emissions over the Bohai Sea (BSA), the YRD and the Pearl River Delta (PRD) (latitude: $21.5-23.8^{\circ} \mathrm{N}$, longitude: $112-115.5^{\circ} \mathrm{E}$ ) (Chen et al., 2017). In this study, we mainly discuss possible effects of shipping-originated aerosols on marine clouds over East China Sea areas using various space-based measurements made in 2014.

\section{Remote Sensing Datasets MODIS}

The Moderate Resolution Imaging Spectroradiometer (MODIS) sensor is aboard the Terra and Aqua satellites (Levy et al., 2007). Aerosol products are derived from MODIS data, among which AOD is retrieved using a dark target algorithm or deep blue algorithm (Remer et al., 2005). The standard MODIS Collection 4 Level 2 AOD and FMF (Optical_Depth_Ratio_Small_Ocean) data product was used for identifying the ship aerosols and sea salt aerosols in the study sea area. The standard MODIS Collection 8 Level 3 daily data product at a spatial resolution of $1^{\circ} \times 1^{\circ}$ was used for obtaining the spatial distribution of $\mathrm{AOD}_{\text {ship }}$ and the analysis of the relationships between $\mathrm{AOD}_{\text {ship }}$ and cloud properties without distinguishing aerosol-cloud overlap, in combination with that from Terra at 10:30 LT and that from Aqua at 13:30 LT (https://ladsweb.modaps.eosdis.nasa. gov). Moreover, the corresponding cloud properties were used to match with AOD, including cloud fraction (CF), cloud effective radius in the liquid phase (CER), cloud optical thickness (COT) and cloud water path in the liquid phase (LWP).

\section{CALIPSO and CloudSat}

Along with the Aqua satellite, CloudSat, a cloudobserving satellite, and Infrared Pathfinder Satellite Observation (CALIPSO) currently fly in the "A-train" satellite constellation (Stephens et al., 2002). The Cloud Profiling Radar (CPR) sensor is aboard CloudSat to capture 


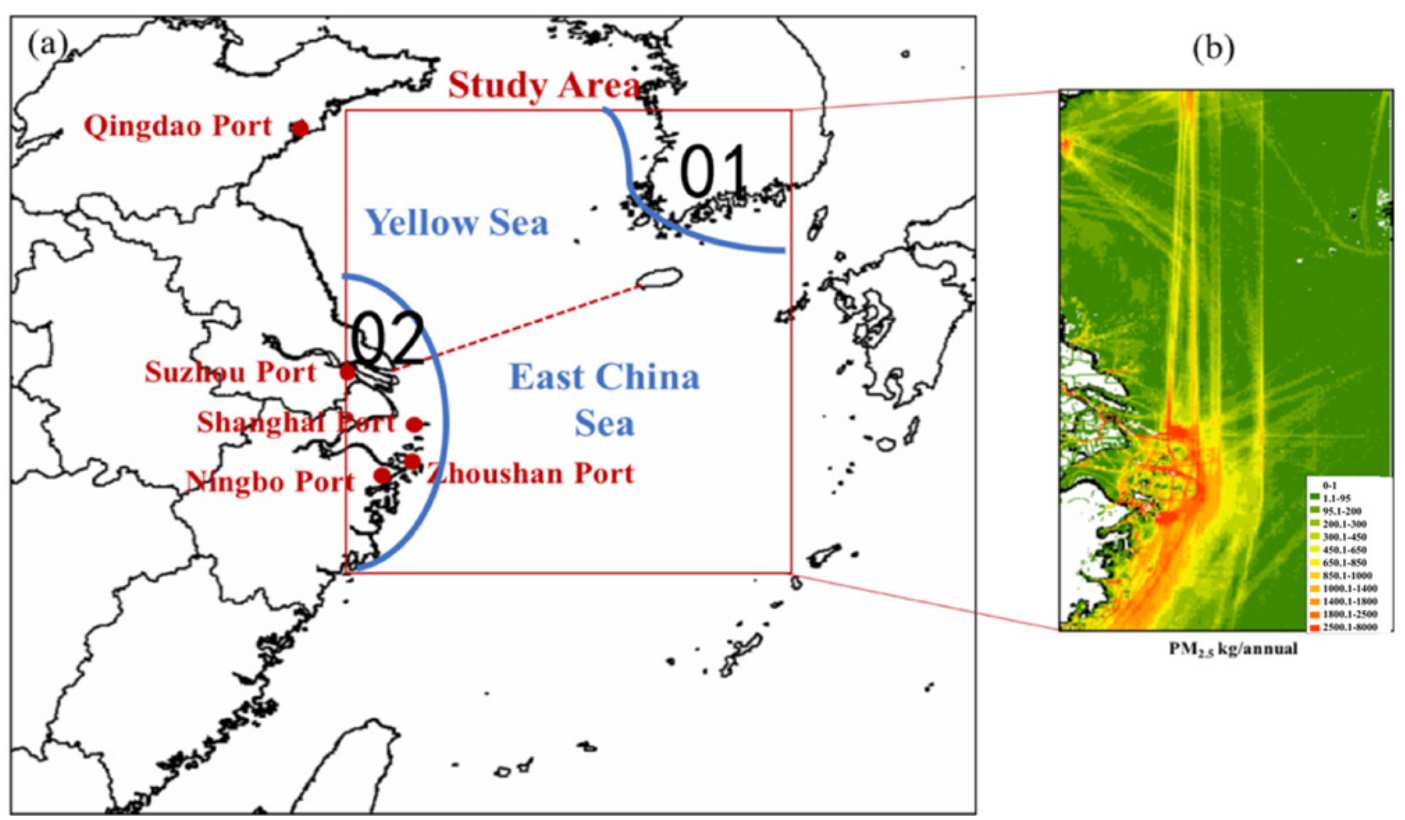

Fig. 1. Schematic diagram of (a) the study area and locations of giant ports, and (b) the spatial distribution of estimated annual $\mathrm{PM}_{2.5}$ emissions from shipping in 2014 (Chen et al., 2017).

the vertical structure information of clouds (especially optically thick clouds) (Im et al., 2005; Wang et al., 2013). Thus, CloudSat is more comprehensive in capturing the vertical structure information of clouds. In this study, we utilized the datasets of $\mathrm{RO}$ _liq_effective_radius and RO_liq_water_content (2B-CWC-RO.P_R 04$)$ and MODIS Cloud Fraction 2B GEOPROF - (2BGEOPROF.P_R05), which are the CloudSat standard data products with a vertical resolution of $480 \mathrm{~m}$ and horizontal resolutions of approximately $1.4 \times 1.8 \mathrm{~km}$ (http://www.clo udsat.cira.colostate.edu).

CALIOP (Cloud Aerosol Lidar with Orthogonal Polarization (CALIOP) on board the CALIPSO is able to detect aerosol and cloud information (Winker et al., 2003). CPR usually miss the optically thin clouds, while CALIOP is sensitive to that (Wang et al., 2013). In this study, we used the CALIOP Level 2 Cloud Layer product and CALIOP Level 2 Vertical Feature Mask product (https://wwwcalipso.larc.nasa.gov). The vertical resolution of the CALIOP profile product is $60 \mathrm{~m}$ from a height of $-0.5 \mathrm{~km}$ to $20.2 \mathrm{~km}$, and the horizontal resolution is $5 \mathrm{~km}$ (Liu et al., 2009). The vertical resolution of the CALIOP Vertical Feature Mask product is $30 \mathrm{~m}$ from $-0.5 \mathrm{~km}$ to $8.2 \mathrm{~km}, 60$ $\mathrm{m}$ from $8.2 \mathrm{~km}$ to $20.2 \mathrm{~km}$, and $180 \mathrm{~m}$ from $20.2 \mathrm{~km}$ to $30.1 \mathrm{~km}$. The spatial resolution of the CALIOP Vertical Feature Mask product is $333 \mathrm{~m}$ from $-0.5 \mathrm{~km}$ to $8.2 \mathrm{~km}$, $1000 \mathrm{~m}$ from $8.2 \mathrm{~km}$ to $20.2 \mathrm{~km}$, and $1667 \mathrm{~m}$ from $20.2 \mathrm{~km}$ to $30.1 \mathrm{~km}$. Combining CloudSat and CALIPSO observations provides new insights into studying the vertical structure and physical properties of clouds (Matrosov, 2007).

\section{Meteorological Data}

Meteorological condition and aerosol effects on cloud physical properties are closely related (Stevens and Feingold, 2009). Relative humidity (RH) and pressure vertical velocity (PVV) that indicates a vertical movement of air mass can affect the relationship between aerosols and clouds (Small et al., 2011; Gryspeerdt et al., 2014). The daily wind speed (WS), wind direction (WD) and $\mathrm{RH}$ at $950 \mathrm{hPa}$ and the PVV at $750 \mathrm{hPa}$ were obtained from the Final Analysis (FNL) of the National Centers for Environmental Prediction (NCEP). The daily FNL data contains global meteorological fields with $1^{\circ} \times 1^{\circ}$ grid horizontal resolution and 26 levels of vertical resolution $(10-1000 \mathrm{hPa})$ every $6 \mathrm{~h}$. Detailed dataset information is shown in Table 1.

\section{Methodology}

To maximize the amount of AOD data during targeted periods, we regarded available values observed by either morning or afternoon satellites as the daily AOD of the individual day. When both morning and afternoon measurements were available, their arithmetic average was used as the daily AOD. Otherwise, when they both were unavailable, the daily AOD was viewed as null.

Firstly, the sum of the shipping-originated aerosol AOD and sea salt $\mathrm{AOD}\left(\mathrm{AOD}_{\text {ship }}+\mathrm{AOD}_{\mathrm{ss}}\right)$ for the study area was screened out based on the FNL data of wind speed and wind direction. In the case that the $u$ component of wind at the 02 area is less than 0 and the $v$ component of wind at the 01 area is greater than 0 , whatever the wind speed is, the aerosols are believed to originate from shipping emissions and sea salt, and they contribute mainly to AOD. When the $u$ component of wind at the 02 area is greater than 0 and less than $2.5 \mathrm{~m} \mathrm{~s}^{-1}$ (Nilsson et al., 2001) and the $v$ component of wind at the 01 area is greater than $-2.5 \mathrm{~m} \mathrm{~s}^{-1}$ (Nilsson et al., 2001) and less than 0, under which the effect of continental aerosols on total aerosol loading is ignorable and can be excluded, the shipping-originated aerosols and sea salt are also considered as the major contributor to AOD. As wind blows almost from the sea in other areas 
Table 1. MODIS, CALIPSO, CloudSat and FNL products used to characterize aerosol and cloud properties.

\begin{tabular}{lll}
\hline Data source & Product & Dataset \\
\hline MODIS & Aerosol (Level 3) & Aerosol_Optical_Depth_Land_Ocean \\
& Aerosol (Level 2) & Optical_Depth_Land_And_Ocean \\
& Optical_Depth_Ratio_Small_Ocean \\
& & Cloud_Effective_Radius_Liquid \\
Cloud (Level 3) & Cloud_Water_Path_Liquid \\
CALIPSO & Cloud_Fraction Cloud_Optical_Thickness_Liquid \\
& Cloud (CPro Level 2) & Column_Optical_Depth_Aerosols_532 \\
Certical Feature Mask (Level 2) & Column_Optical_Depth_Cloud_532 \\
& Cloud (2B-GEOPROF.P_R05) & Feature_Classification_Flags \\
& Cloud (2B-CWC-RO.P_R04) & MODIS_Cloud_Fraction_2B_GEOPROF \\
& RO_liq_effective_radius \\
FCEP & RO_liq_water_content \\
& & Wind speed (950 hPa) \\
& & Wind direction (950 hPa) \\
& Relative humidity (950 hPa) \\
& & Pressure vertical velocity (750 hPa)
\end{tabular}

(excluding 01 and 02 areas), AOD is totally dominated by sea salt aerosols or shipping-originated aerosols. Secondly, based on the criteria for aerosol classification proposed by He et al. (2012), $0<\mathrm{AOD}<0.5$ and $0.25 \leq \mathrm{FMF}<0.7$ were selected as criteria for identifying ship and sea salt aerosols (excluding other aerosols) in the study area. The combination of the two methods can effectively exclude the influence of long-distance transport aerosols (dust, continental) and can more accurately identify ship and sea salt aerosols. The statistical results of screened $\mathrm{AOD}_{\text {ship }}$ plus $\mathrm{AOD}_{\mathrm{ss}}$ over the study area are shown in Table 2 . According to previous research (Kaskaoutis et al., 2007), when $0<\mathrm{AOD}<0.2$ and $0 \leq \mathrm{FMF}<0.7$, the aerosol type is classified as clean ocean aerosol $\left(\mathrm{AOD}_{\mathrm{ss}}\right)$, and the spatio-temporal distributions of $\mathrm{AOD}_{\mathrm{ss}}$ have little change. In this study, we chose 0.15 as the background $\mathrm{AOD}_{\mathrm{ss}}$ (Fan et al., 2011), and then we roughly calculated $\mathrm{AOD}_{\text {ship }}$ by subtracting the background $\mathrm{AOD}_{\mathrm{ss}}$ from $\mathrm{AOD}_{\text {ship+ss }}$ that was greater than 0.15 . If $\mathrm{AOD}_{\text {ship+ss }}$ was less than 0.15 , $\mathrm{AOD}_{\text {ship }}$ was regarded as 0 . Finally, the spatial distributions of $\mathrm{AOD}_{\text {ship }}$ in spring (MAM), summer (JJA), autumn (SON) and winter (DJF) were achieved by the above method.

Referring to the study of Costantino and Bréon (2013), in the case of the vertical distance between the bottom of the aerosol layer and the top of the cloud layer was smaller than $100 \mathrm{~m}$ or the vertical distance between the top of the aerosol layer and the bottom of the cloud layer was smaller than $100 \mathrm{~m}$, aerosol and cloud layers were considered to be physically interacting (well mixed) (Fig. 2(a)). When their vertical distance exceeded $750 \mathrm{~m}$, aerosol and cloud layers

Table 2. The statistical results of AOD affected by ships and sea salt.

\begin{tabular}{ll}
\hline Season & Days \\
\hline Spring (MAM) & 37 \\
Summer (JJA) & 48 \\
Autumn (SON) & 63 \\
Winter (DJF) & 36 \\
\hline
\end{tabular}

were considered to be separated (Fig. 2(b)). Other conditions were not taken into consideration in this study. The aerosol and cloud types were defined using the Feature_Classification_Flags (FCF) derived from CALIPSO. Moreover, AOD and COD datasets from CALIPSO, and CF, CER and LWC datasets from CloudSat were used to explore the interaction between aerosol and cloud layers at different heights. Although the detection times of the two satellites have a gap of 12.5 seconds, they can detect the same cloud layer at almost the same time.

\section{RESULTS AND DISCUSSION}

\section{Spatial Distributions of $A O D_{\text {ship }}$}

$\mathrm{AOD}_{\text {ship }}$ is influenced by shipping-originated aerosols, such as primary particles, OC, EC and other secondary pollutants. Fig. 3 shows the spatial distributions of $\mathrm{AOD}_{\text {ship }}$ in spring (MAM), summer (JJA), autumn (SON) and winter (DJF). Clearly, the mean $\mathrm{AOD}_{\text {ship }}$ over the study area was approximately $0.17,0.20,0.15$ and 0.13 in four seasons, and accounted for $23 \%, 30 \%, 36 \%$ and $25 \%$ of total AOD, respectively. The maximum $\mathrm{AOD}_{\text {ship }}$ appeared in summer due to relatively higher aerosol loading and atmospheric $\mathrm{RH}$, during which increased particles from shipping emissions and their hygroscopic growth can magnify aerosol extinction to solar radiation (Xin et al., 2014).

Over remote sea areas, in spring and summer, $\mathrm{AOD}_{\text {ship }}$ was generally higher mainly due to high RH and effective sunlight, while in autumn, $\mathrm{AOD}_{\text {ship }}$ was lower due to the prevailing northeast wind usually bringing clean air. Shen et al. (2019) also found low AOD during autumn over Yellow and Bohai Sea. In winter, the atmospheric circulation over the NECS was dominated by strong nearzone continental outflow in the middle atmosphere, and northwesterly winds prevailing in the boundary layer. This air current situation provides an effective approach to transporting pollutants originating from large discharge areas to the NECS after a long distance. 

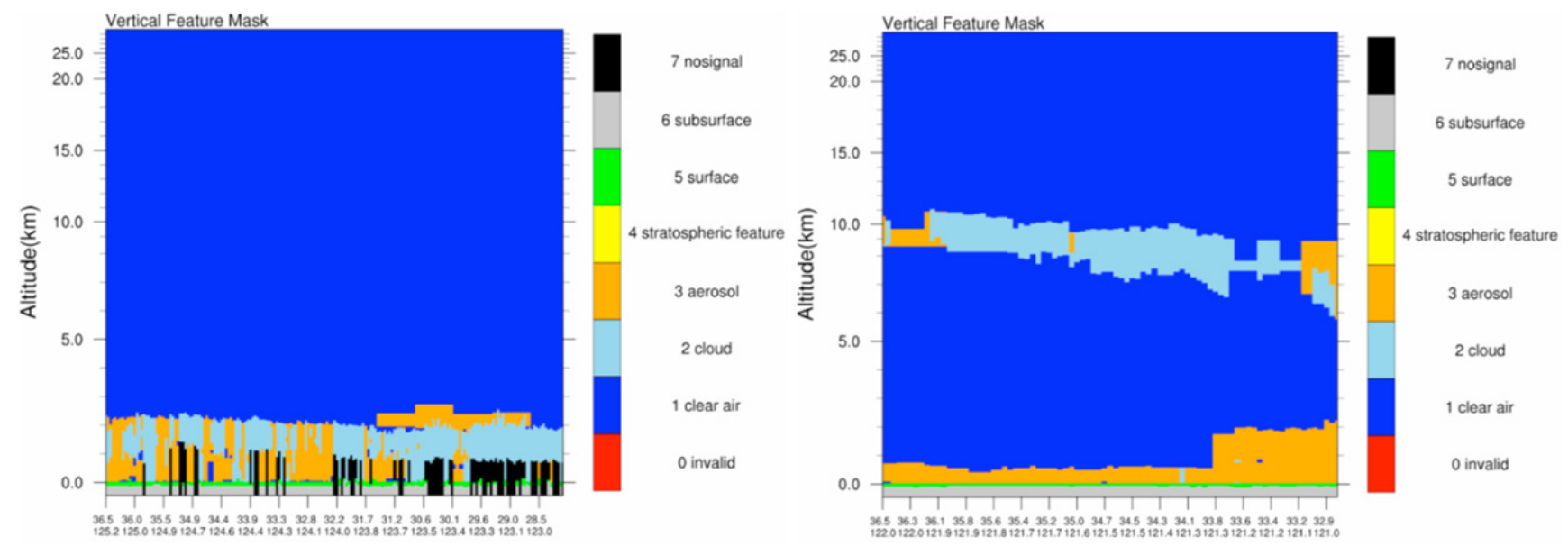

Fig. 2. Vertical features of aerosol and cloud layers from CALIPSO in cases of (a) 16 January and (b) 15 June.

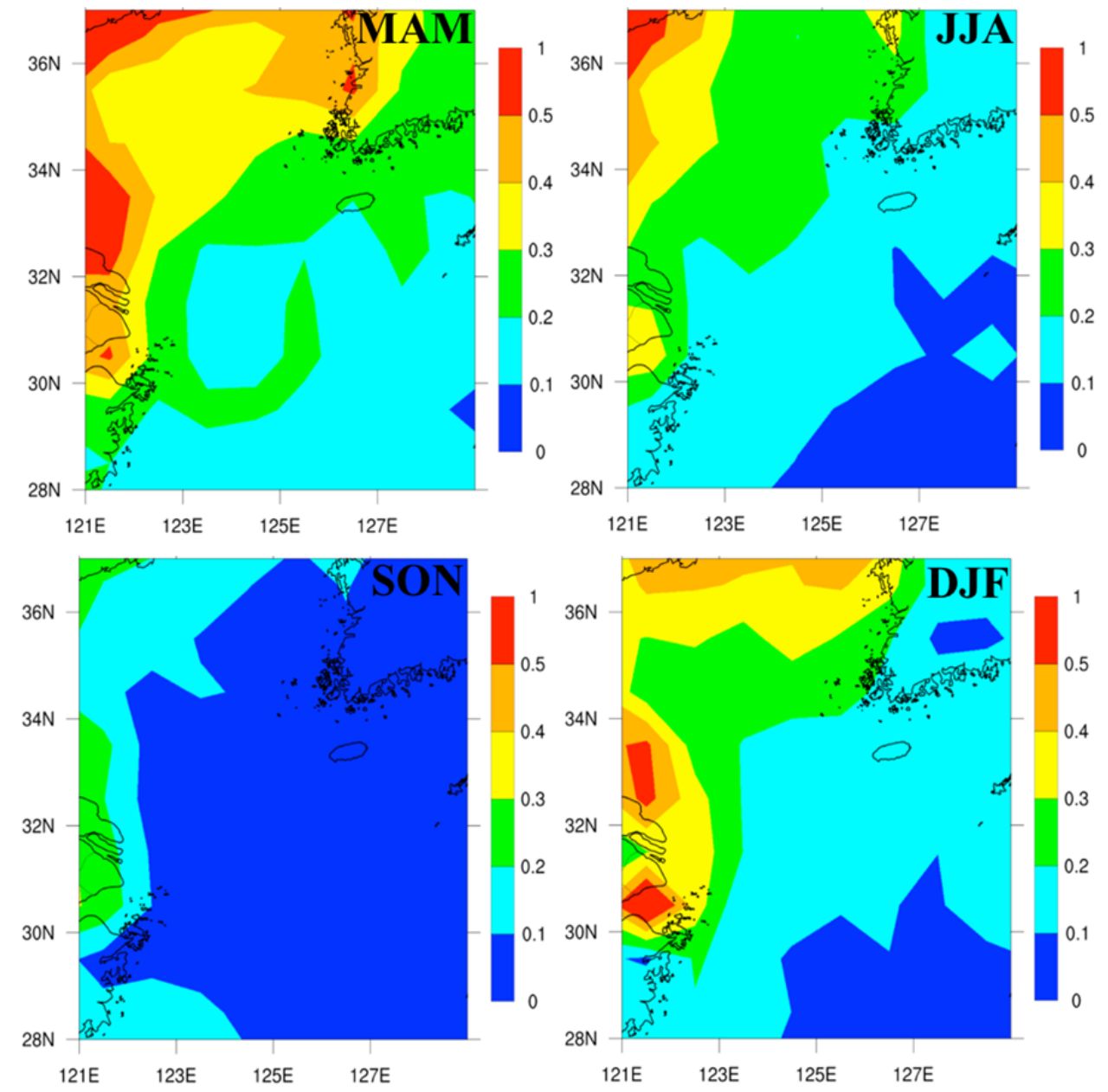

Fig. 3. The spatial distributions of shipping-originated aerosol $A_{O} D_{\text {ship }}$ in spring (MAM), summer (JJA), autumn (SON) and winter (DJF) of 2014.

\section{Relationships between Cloud Properties and AOD}

The effect of $\mathrm{AOD}_{\text {ship }}$ on cloud properties and the relationships between them without distinguishing aerosolcloud overlap were discussed using MODIS 08 datasets. Fig. 4 shows the spatial and seasonal distributions of correlation coefficients of $\mathrm{AOD}_{\text {ship }}$ versus COT (top), CER (middle; LWP is held fixed) and CF (bottom), where the black dot areas pass the significance test $(\partial=0.05)$.

COT vs. $A O D_{\text {ship }}$

In general, COT decreased with increasing $\mathrm{AOD}_{\text {ship }}$ during all four seasons, which implies that clouds possibly 

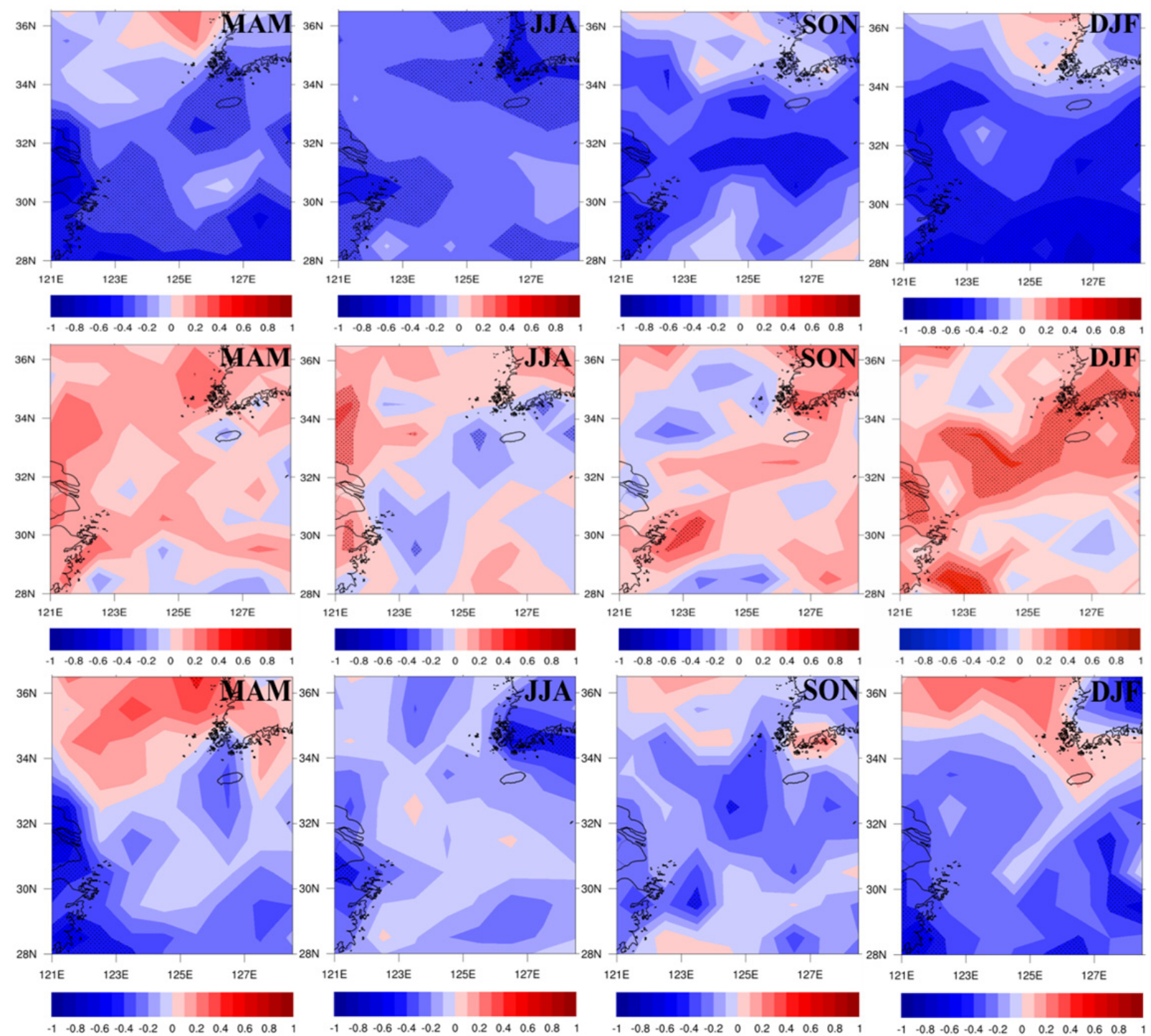

Fig. 4. The spatial distributions of correlation coefficients between $\mathrm{AOD}_{\text {ship }}$ and COT (top), CER (middle) and CF (bottom) in the spring, summer, autumn and winter of 2014. The black dot areas passed the significance test $(\partial=0.05)$.

become optically thinner as more shipping-originated particles are carried into clouds by airflow (Fig. 4). Clearly, an obvious correlation between $\mathrm{AOD}_{\text {ship }}$ and COT existed over the offshore areas of East China. In spring and winter, a negative correlation existed between $\mathrm{AOD}_{\text {ship }}$ and COT over the southern areas of NECS, with correlation coefficients $(\mathrm{R})$ of -0.42 and 0.51 , respectively. In the autumn, although $\mathrm{AOD}_{\text {ship }}$ over remote sea areas was low, the correlation between $\mathrm{AOD}_{\text {ship }}$ and COT over these areas was better than in the other three seasons.

Two possible effects are considered to be responsible for the above negative relationships. Firstly, cloud droplets evaporate due to the absorbing aerosols (such as black carbon) and then clouds become thinner, which is called the radiative effect (Liu et al., 2017). Black carbon is a highly condensed carbonaceous residue arising from incomplete combustion and is a major light-absorbing component in atmospheric aerosols (Wu et al., 2016). Secondly, the absorbing aerosols may affect the retrieved
COT from satellite due to the radiation effects and then decrease the cloud reflectance (Ten Hoeve et al., 2011; Li et al., 2014; Meyer et al., 2015). Alam et al. (2014) also indicated that due to the effects of absorbing aerosols the detected cloud reflectance from the cloud top at visible wavelengths is usually smaller than expected. Meyer et al. (2013) pointed out that for the clouds in polluted marine boundary layer, adjusting the aerosol attenuation above the cloud can increase the average regional retrieved COT by approximately $18 \%$. Thus, the radiative effect and the retrieval uncertainty play an important role in the relationship between COT and AOD.

CER vs. $A O D_{\text {ship }}$

There was a positive correlation $(\mathrm{R}=0.35)$ between $\mathrm{CER}$ and $\mathrm{AOD}_{\text {ship }}$ in the winter but a weakly negative correlation $(\mathrm{R}=-0.17)$ in the summer over the NECS and a positive correlation in the spring and summer over the YS (Fig. 4). Feingold et al. (1999) found that slightly 
soluble organic particles (SSO) and giant cloud condensation nuclei $(\mathrm{CCN})$ present in the ship-originated aerosols, and even low concentrations of larger $\mathrm{CCN}$ emitted from ship can affect cloud properties. Yuan et al. (2008) concluded that there was a positive correlation between AOD and CER over East China due to the effects of SSO and larger CCN. Yuan et al. (2008) explained that the presence of SSO and larger $\mathrm{CCN}$ increased the AOD and decreased the total cloud droplets and thus CER increased according to the simulation of the 2-D Goddard Cumulus Ensemble model. The reason is that almost all SSO are difficult to be activated and hydrophobic as well as larger $\mathrm{CCN}$ prefer to absorb water vapor because of their lower critical supersaturation, leading to the deactivation of small aerosol particles (Rosenfeld et al., 2002). Tang et al. (2014) observed that when AOD was greater than 0.3 , positive correlations contrary to the Twomey effect between CER and AOD existed over the YS area in summer, whereas negative correlations consistent with the Twomey effect existed over the NECS area when AOD was less than 0.3. The present study showed that negative correlations between CER and $\mathrm{AOD}_{\text {ship }}$ appeared over the NECS for $\mathrm{AOD}_{\text {ship }}$ less than 0.2 during summer, whereas positive correlations between them over the YS for $\mathrm{AOD}_{\text {ship }}$ greater than 0.2.

\section{CF vs. $A O D_{\text {ship }}$}

There was a negative correlation $(\mathrm{R}=-0.23)$ between $\mathrm{CF}$ and $\mathrm{AOD}_{\text {ship }}$ during all four seasons over the coastal areas of the NECS due to more primary particles and a weakly positive correlation during the spring over the YS due to aged particles (Fig. 4). The evaporation of cloud droplets caused by absorbing aerosols always makes clouds thinner (Liu et al., 2017). For the positive correlation, the possible interpretation is that the retrieved AOD becomes higher with increased clear-sky reflectance close to cloud edges due to the 3-D effects (Várnai and Marshak, 2009). Other possible interpretations are higher humidity leading to greater aerosol volume near clouds (Twohy et al., 2009) as well as convergence resulting in thicker aerosol layers (Mauger and Norris, 2007).

\section{Differences between Separated and Mixed Aerosol-cloud Layers}

In the view of climatology, in spite of correlation existing between cloud properties and AOD, the aerosol effects on cloud physical properties cannot be fully understood. Aerosols are often pinched into the cloud body to affect the microphysical properties of cloud droplets and participate in cloud formation and disappearance processes. Aerosolcloud overlap is a typical situation used to investigate the direct influence of aerosol particles on clouds in the vertical direction through convection or entrainment. We examined the response of cloud physical properties to increasing $\mathrm{AOD}_{\text {ship }}$ for separated and mixed overlaps of aerosol and cloud layers based on CALIPSO and CloudSat datasets. Fig. 5 shows the relationship between major cloud parameters and $\mathrm{AOD}_{\text {ship }}$ under two aerosol-cloud overlap conditions. Commonly, in the case of aerosol-cloud mixed overlap, the cloud properties of COD, CER (LWC is held fixed) and $\mathrm{CF}$ had negative correlations with $\mathrm{AOD}_{\text {ship }}$

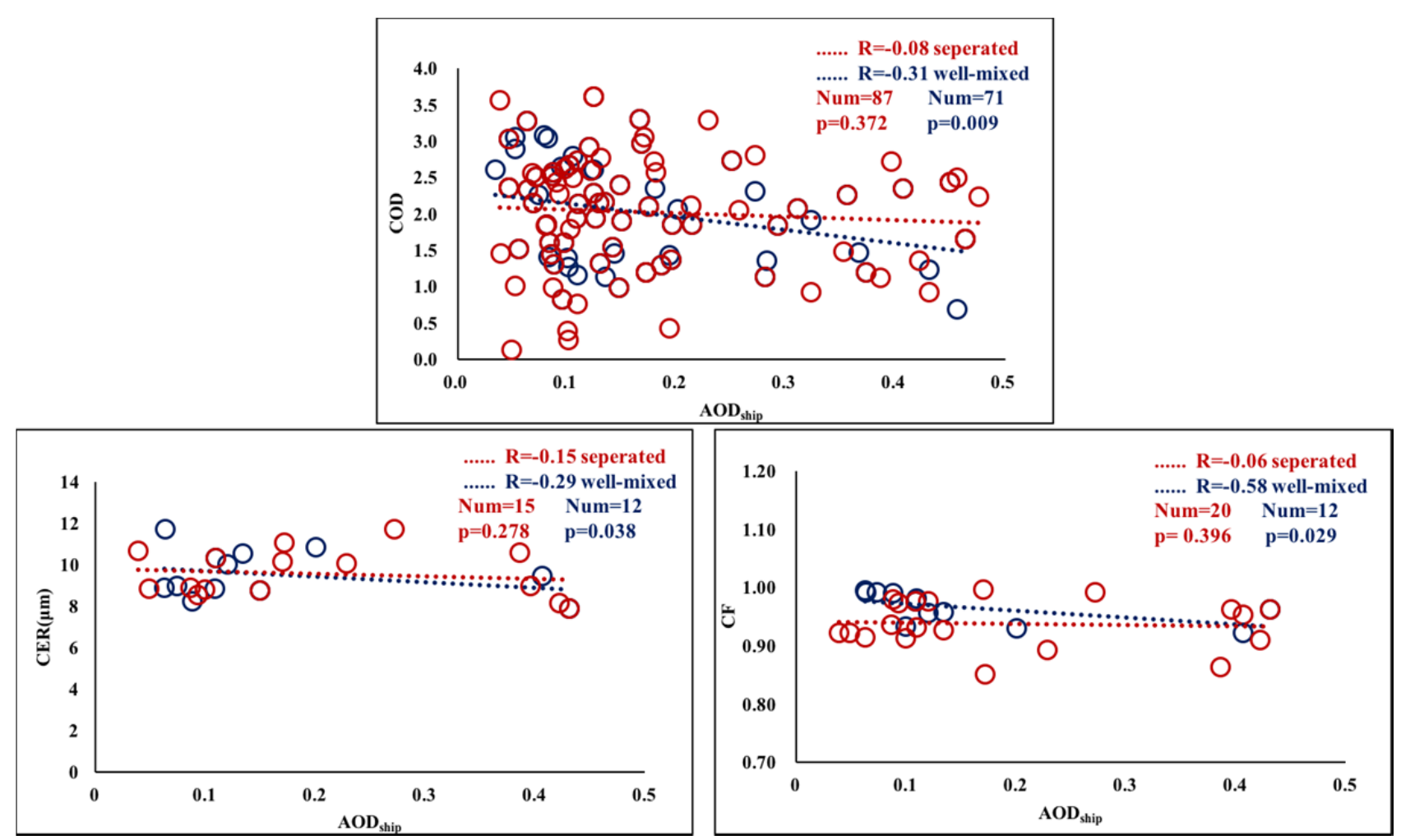

Fig. 5. Scatter plots of cloud parameters versus $\mathrm{AOD}_{\text {ship }}$ for cases of vertical separated (red) and well-mixed (blue) aerosolcloud layers. 
(absolute $\mathrm{R}>0.3$ ). Whereas in the case of aerosol-cloud separated overlap, the above parameters showed weaker negative or positive correlations.

The relationship between $\mathrm{COD}$ and $\mathrm{AOD}_{\text {ship }}$ indicates that at mixed overlap, the evaporation of cloud droplets causes clouds to be thinner by shipping-originated absorbing aerosols. The relationship between CER and $\mathrm{AOD}_{\text {ship }}$ indicates that when uplifted shipping-emitted aerosols enter into the cloud body, the cloud droplets increase and thus CER decreases. However, when aerosol and cloud layers are separated, CER varies much less with $\mathrm{AOD}_{\text {ship, }}$ as there are no interactions between aerosols and clouds resulting from no aerosols directly participating in cloud microphysical processes. Liu et al. (2017) revealed that CF is smaller due to the presence of smoke. Shipping-originated aerosols are composed of completely smoke-containing fine absorbing particles and result in an increase of small droplets through the evaporation of cloud droplet water and the reduction of cloud cover due to the promotion of aerosol efficiency to sunlight absorption.

\section{Meteorological Effects on AOD ship and Cloud Properties}

Feingold et al. (2001) pointed that aerosol hygroscopicity and PVV played an important role on aerosols' indirect effect. Wang et al. (2014b) demonstrated that the dynamic and thermodynamic processes in the cloud systems can influence the aerosol-cloud interactions. To investigate whether the aerosol (e.g., CCN) variations are relevant with systematic meteorological situations, we focused on the regional-scale changes of air vertical motion (PVV) and RH. Based on the findings of the previous section, we will focus on the relationship between $\mathrm{AOD}_{\text {ship }}$ and cloud properties under well-mixed overlap conditions.

\section{Relative Humidity}

Relative humidity is an important factor that influences aerosol particle size and cloud development. High RH at the bottom of the cloud can influence the relationship between aerosols and clouds (Small et al., 2011). According to RH at $950 \mathrm{hPa}$, we took $\mathrm{RH}=80 \%$ as the cut-off value and analyzed the relationships of cloud properties versus $\mathrm{AOD}_{\text {ship }}$ at classified RH levels. Fig. 6 shows the relationships between cloud properties and $\mathrm{AOD}_{\text {ship }}$ for cases of low $\mathrm{RH}$ $(<80 \%)$ and high $\mathrm{RH}(>80 \%)$.

As shown in Fig. 6, the correlation coefficients between cloud parameters and $\mathrm{AOD}_{\text {ship }}$ were generally higher at high RH (absolute $\mathrm{R}>0.3$ ) than at low RH. Meanwhile, the values of cloud parameters were higher at high $\mathrm{RH}$ than at low RH for the same level of $\mathrm{AOD}_{\text {ship. Obviously, }}$ there was a turning point of $\mathrm{AOD}_{\text {ship }}$ ranging from 0.3 to 0.4 for the correlation between cloud parameters and

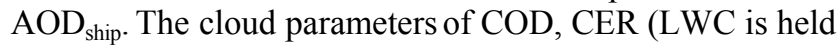
fixed) and $\mathrm{CF}$ decreased with increasing $\mathrm{AOD}_{\text {ship }}$ at $\mathrm{RH}>$ $80 \%$, but in contrast, at $\mathrm{RH}<80 \%$, the results indicated that the ship-originated aerosols that were rolled into the cloud body could influence cloud properties by increasing the cloud condensation nuclei $(\mathrm{CCN})$ number at low aerosol loadings and possibly by enhancing the warming of absorbing particles at high aerosol loadings. This implies that it is easy to form optically thicker and higher clouds
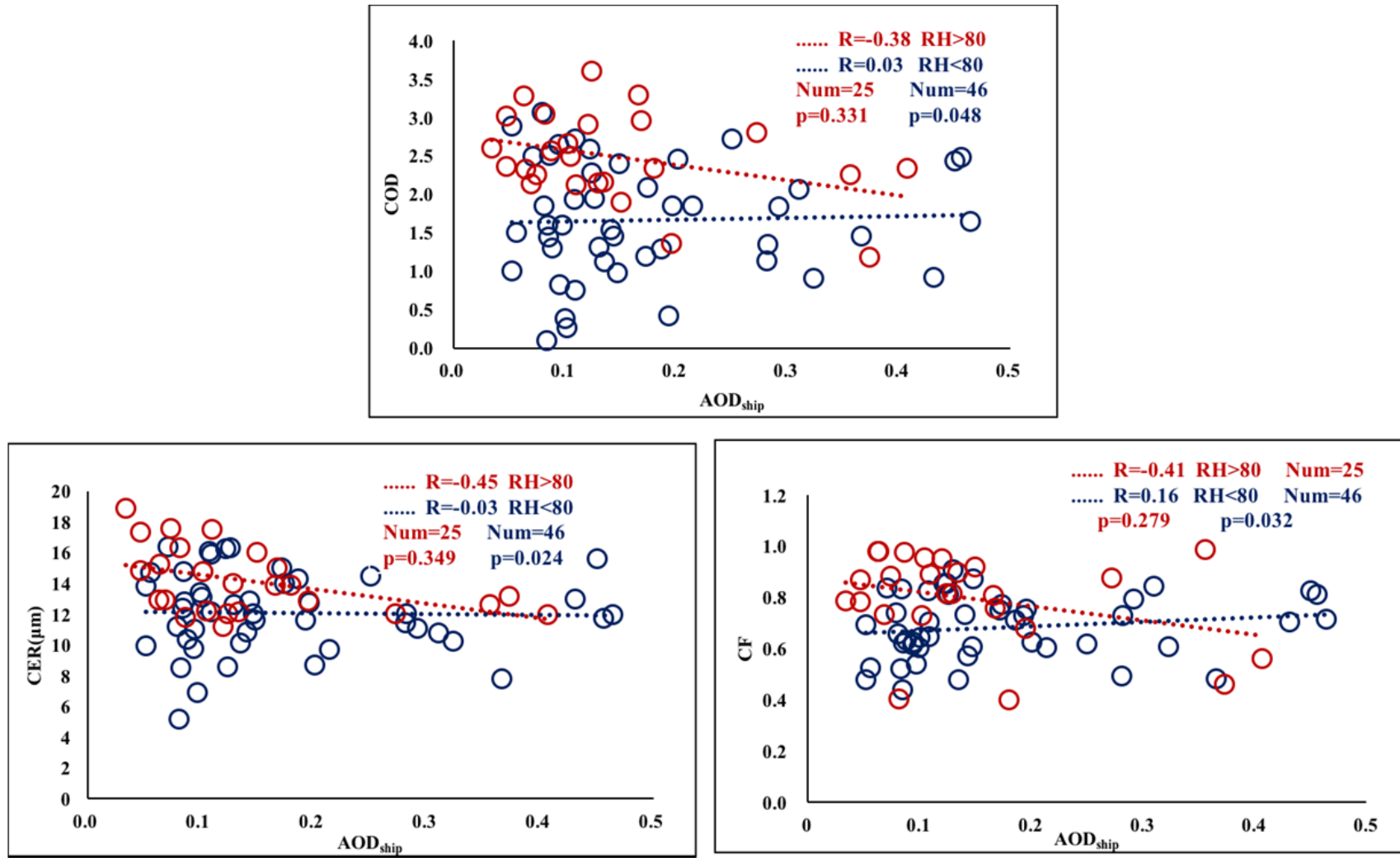

Fig. 6. Scatter plots of cloud parameters versus $A_{O} D_{\text {ship }}$ for cases of high RH (red) and low RH (blue) at $950 \mathrm{hPa}$. 
under high $\mathrm{RH}$ condition. The possibility of cloud droplet activation as well as the growth of cloud droplets increases with RH (Jones et al., 2009). This indicates that high RH contributes to larger cloud droplets because of higher water vapor content existing in the atmosphere.

\section{Pressure Vertical Velocity}

$\mathrm{PVV}$ at $750 \mathrm{hPa}$ is commonly used as a meteorological indicator of atmospheric dynamic state. For low index cloud regimes, PVV is treated as a good proxy of the mean convective air mass flux simulated by Fan et al. (2011). The presence of upward motion is favorable for cloud formation due to the ambient environment, which is called negative PVV, and can also promote aerosol and cloud interactions (Jones et al., 2009). In the present study, high frequency of mixed aerosol-cloud mixture occurred at a low and medium level of cloud height less than $6 \mathrm{~km}$. Thus, PVV at $750 \mathrm{hPa}$ was chosen to represent atmospheric dynamic state. Fig. 7 shows the relationships between cloud properties with $\mathrm{AOD}_{\text {ship }}$ for cases of negative PVV $(<0)$ and positive PVV $(>0)$.

As shown in Fig. 7, the correlation coefficients between cloud parameters and $\mathrm{AOD}_{\text {ship }}$ were generally higher at negative PVV than at positive PVV. Meanwhile, the values of cloud parameters were higher at negative PVV than at positive PVV for the same level of $\mathrm{AOD}_{\text {ship. This }}$ implies that negative PVV favors the formation of optically thicker clouds as well as larger cloud droplets. Additionally, negative PVV can also promote cloud development and increase cloud cover.

\section{CONCLUSIONS}

The effects of shipping emissions on the micro- and macrophysical properties of clouds in marine areas near East China were investigated from a climatological perspective using multi-satellite datasets for the year 2014. Statistical

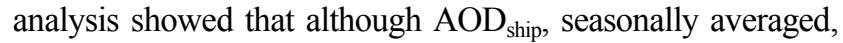
was higher in spring and summer, its contribution to the total AOD was higher in summer and autumn. The quantity of shipping-originated aerosols (based on $\mathrm{AOD}_{\text {ship }}$ ) is correlated with the major micro- and macro-scale physical cloud properties (COT, CF and CER), in spite of differences in time and place (e.g., offshore or remote sea areas). Irrespective of the thermodynamic structures, such as water vapor and upward air motion, a low cloud bottom facilitates the updraft of shipping-originated aerosols and contributes to the formation and development of clouds above the aerosol layer. Overall, shipping emissions may affect clouds by increasing the number of cloud condensation nuclei $(\mathrm{CCN})$ at low aerosol loadings and by warming absorbing particles at high aerosol loadings.

How aerosols directly affect clouds and precipitation and thus the global climate remains a challenging question due to the complex mechanisms driving atmospheric thermodynamic conditions and aerosol-cloud interaction. In the future, we will extend our research on shipping-originated aerosol effects in marine areas by applying numerical
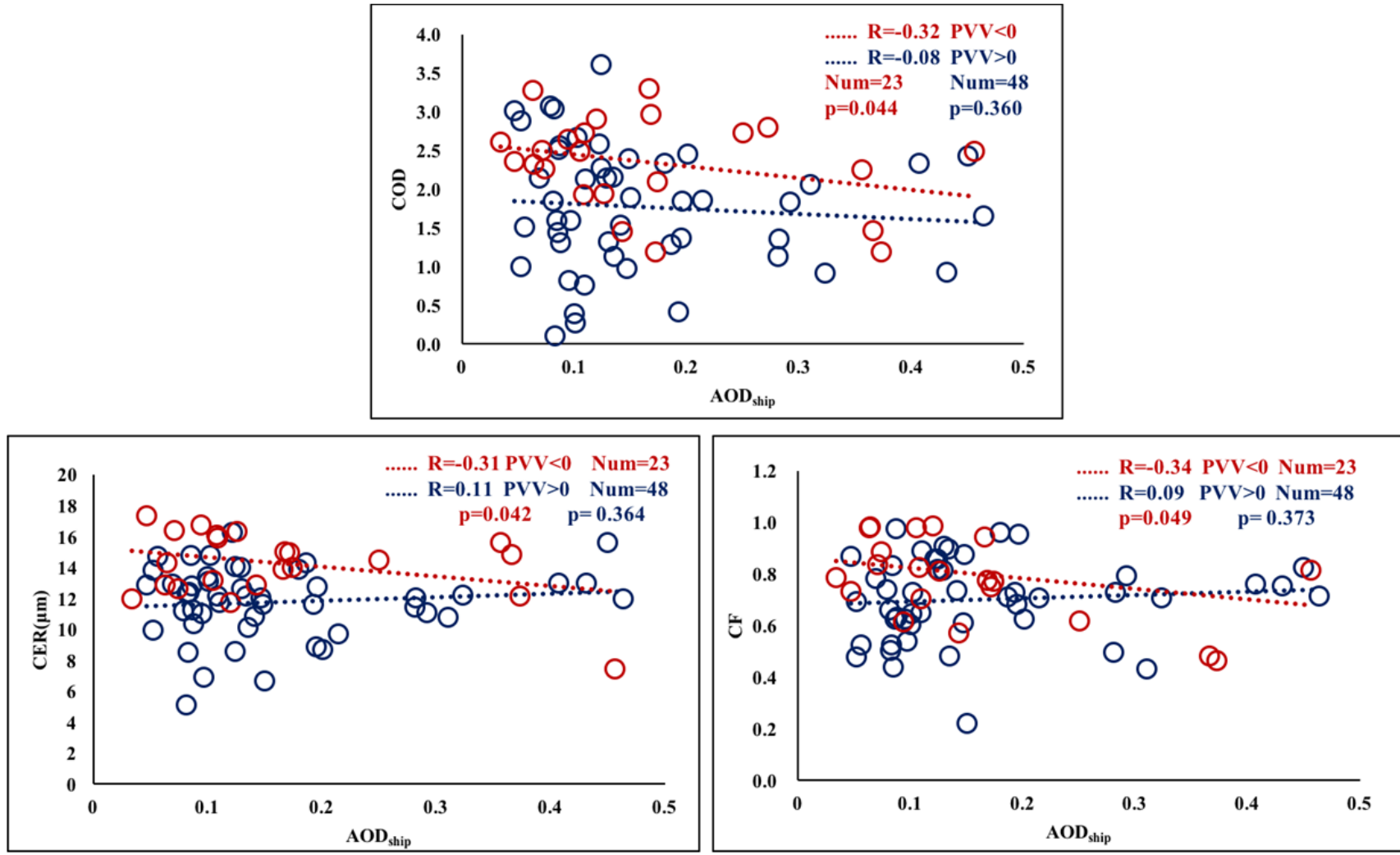

Fig. 7. Scatter plots of the cloud parameters versus $A_{O D}$ ship for cases of negative PVV (red) and positive PVV (blue) at $750 \mathrm{hPa}$. 
models and big data technology (Wang and Zhao, 2016; $\mathrm{Wu}, 2016$ ), which supply relatively complete descriptions of physical and chemical processes in the atmosphere, and by assessing the influence of the major ship-emitted chemical species.

\section{ACKNOWLEDGEMENTS}

This research is supported by the National Key R\&D Program of China (2016YFC0201900, 2017YFC1501701, 2017YFC1501405, 2016YFC0202003), the National Natural Science Foundation of China (41775129, 91637101, 41475040, 41675111), and partly by the Science and Technology Commission of Shanghai Municipality (16ZR1431700). The authors gratefully acknowledge the science data support teams for MODIS, CALIPSO and CloudSat products and the Earth Observing System Data Gateway for processing and distributing the data used in this paper.

\section{REFERENCES}

Alam, K., Khan, R., Blaschke, T. and Mukhtiar, A. (2014). Variability of aerosol optical depth and their impact on cloud properties in Pakistan. J. Atmos. Sol. Terr. Phys. 107: 104-112.

Albrecht, B.A. (1989). Aerosols, cloud microphysics, and fractional cloudiness. Science 245: 1227-1230.

Bennartz, R., Fan J., Rausch, J., Leung, L.R. and Heidinger, A.K. (2011). Pollution from China increases cloud droplet number, suppresses rain over the East China Sea. Geophys. Res. Lett. 38: L09704.

Cappa, C.D., Williams, E.J., Lack, D.A., Buffaloe, G.M., Coffman, D., Hayden, K.L., Herndon, S.C., Lerner, B.M., Li, S.M., Massoli, P., McLaren, R., Nuaaman, I., Onasch, T.B. and Quinn, P.K. (2014). A case study into the measurement of ship emissions from plume intercepts of the NOAA ship Miller Freeman. Atmos. Chem. Phys. 14: 1337-1352.

Chen, D.S., Wang, X.T., Li, Y., Lang, J.L., Zhou, Y., Guo, X.R. and Zhao, Y.H. (2017). High-spatiotemporalresolution ship emission inventory of China based on AIS data in 2014. Sci. Total Environ. 609: 776-787.

Chen, Y.C., Christensen, M.W., Xue, L., Sorooshian, A., Stephens, G.L., Rasmussen, R.M. and Seinfeld, J.H. (2012). Occurrence of lower cloud albedo in ship tracks. Atmos. Chem. Phys. 12: 8223-8235.

Coggon, M.M., Sorooshian, A., Wang, Z., Metcalf, A.R., Frossard, A.A., Lin, J.J., Craven, J.S., Nenes, A., Jonsson, H.H., Russell, L.M., Flagan, R.C. and Seinfeld, J.H. (2012). Ship impacts on the marine atmosphere: Insights into the contribution of shipping emissions to the properties of marine aerosol and clouds. Atmos. Chem. Phys. 12: 8439-8458.

Costantino, L. and Bréon, F.M. (2013). Aerosol indirect effect on warm clouds over South-East Atlantic, from co-located MODIS and CALIPSO observations. Atmos. Chem. Phys. 13: 69-88.

Dalsøren, S.B. Eide, M.S. Endresen, Ø. Mjelde, A. Gravir,
G. and Isaksen, I.S.A. (2009). Update on emissions and environmental impacts from the international fleet of ships. The contribution from major ship types and ports. Atmos. Chem. Phys. 9: 2171-2194.

Durkee, P.A. (2000). The impact of ship-produced aerosols on the microstructure and albedo of warm marine stratocumulus clouds: A test of MAST hypotheses $1 \mathrm{i}$ and 1ii. J. Atmos. Sci. 57: 2554-2569.

Fan, Q., Zhang, Y., Ma, W., Ma, H., Feng, J., Yu, Q., Yang, X., Ng, S.K.W., Fu, Q. and Chen, L. (2016). Spatial and seasonal dynamics of ship emissions over the Yangtze River Delta and East China Sea and their potential environmental influence. Environ. Sci. Technol. 50, 1322-1329.

Fan, T. and Toon, O.B. (2011). Modeling sea-salt aerosol in a coupled climate and sectional microphysical model: Mass, optical depth and number concentration. Atmos. Chem. Phys. 11: 4587-4610.

Feingold, G., Cotton, W.R. Kreidenweis, S.M. and Davis, J.T. (1999). The impact of giant cloud condensation nuclei on drizzle formation in stratocumulus: Implications for cloud radiative properties. J. Atmos. Sci. 56: 41004117.

Feingold, G., Remer, L.A., Ramaprasad, J. and Kaufman, Y.J. (2001). Analysis of smoke impact on clouds in Brazilian biomass burning regions: An extension of Twomey's approach. J. Geophys. Res. 106: 22907-22922.

Feingold, G., Eberhard, W., Veron, D. and Previdi, M. (2003). First measurements of the Twomey indirect effect using ground-based remote sensors. Geophys. Res. Lett. 30: 12873.

Gao, W.H., Sui, C.H. and Hu, Z.J. (2014). A study of macrophysical and microphysical properties of warm clouds over the Northern Hemisphere using CloudSat/CALIPSO data. J. Geophys. Res. 119: 32683280 .

Gryspeerdt, E., Stier, P. and Partridge, D.G. (2014). Satellite observations of cloud regime development: The role of aerosol processes. Atmos. Chem. Phys. 14: 11411158.

Hanel, G. (1976). The properties of atmospheric aerosol particles as function of the relative humidity at thermodynamic equilibrium with the surrounding moist air. Adv. Geophys. 19: 73-188.

He, Q., Li, C., Geng, F., Lei, Y. and Li, Y. (2012). Study on long-term aerosol distribution over the land of East China using MODIS data. Aerosol Air Qual. Res. 12: 304-319.

Im, E., Wu, C.L. and Durden, S.L. (2005). Cloud profiling radar for the CloudSat mission. IEEE Aerosp. Electron. Syst. Mag. 20: 15-18.

IPCC (2014). Climate Change 2014: Impacts, Adaptation, and Vulnerability. Contribution of Working Group II to the Fifth Assessment Report of the Intergovernmental Panel on Climate Change. Field, C.B., Barros, V.R., Dokken, D.J., Mach, K.J., Mastrandrea, M.D., Bilir, T.E., Chatterjee, M., Ebi, K.L., Estrada, Y.O., Genova, R.C., Girma, B., Kissel, E.S., Levy, A.N., MacCracken, S., Mastrandrea, P.R. and White, L.L. (Eds.), Cambridge 
University Press, Cambridge, USA.

Jones, T.A., Christopher, S.A. and Quaas, J. (2009). A sixyear satellite-based assessment of the regional variations in aerosol indirect effects. Atmos. Chem. Phys. 9: 40914114.

Juwono, A.M., Johnson, G.R. Mazaheri, M. Morawska, L. Roux, F. and Kitchen, B. (2013). Investigation of the airborne submicrometer particles emitted by dredging vessels using a plume capture method. Atmos. Environ. 73: $112-123$.

Kaskaoutis, D.G., Kosmopoulos, P.H. and Kambezidis, D. (2007). Aerosol climatology and discrimination of different types over Athens, Greece, based on MODIS data. Atmos. Environ. 41: 7315-7329.

Kaufman, Y.J., Koren, I., Remer, L.A., Rosenfeld, D. and Rudich, Y. (2012). The effect of smoke, dust, and pollution aerosol on shallow cloud development over the Atlantic Ocean. Proc. Natl. Acad. Sci. U.S.A. 102: 11207-11212.

Kerminen, K.E., Lehtinen, J., Laakso, L. and Korhonen, H. (2013). Climate and air quality trade-offs in altering ship fuel sulfur content. Atmos. Chem. Phys. 13: 1205912071.

Levy, R.C., Remer, L.A., Mattoo, S., Vermote, E.F. and Kaufman, Y.J. (2007). Second-generation operational algorithm: Retrieval of aerosol properties over land from inversion of moderate resolution imaging spectroradiometer spectral reflectance. J. Geophys. Res. 112: D13211.

Li, Z., Zhao, F., Liu, J., Jiang, M., Zhao, C. and Cribb, M. (2014). Opposite effects of absorbing aerosols on the retrievals of cloud optical depth from spaceborne and ground-based measurements. J. Geophys. Res. 119: 5104-5114.

Liu, Y.Q., Leeuw, G. and Kerminen, V.M. (2017). Analysis of aerosol effects on warm clouds over the Yangtze River Delta from multi-sensor satellite observations. Atmos. Chem. Phys. 17: 5623-5641.

Liu, Z., Vaughan, M., Winker, D., Kittaka, C., Getzewich, B., Kuehn, R., Omar, A., Powell, K., Trepte, C. and Hostetler, C. (2009). The CALIPSO lidar cloud and aerosol discrimination: Version 2 algorithm and initial assessment of performance. J. Atmos. Oceanic Technol. 26: 1198-1213.

Marmer, E. and Langmann, B. (2005). Impact of ship emissions on the Mediterranean summertime pollution and climate: A regional model study. Atmos. Environ. 39: 4659-4669.

Matrosov, S.Y. (2007). Potential for attenuation-based estimations of rainfall rate from CloudSat. Geophys. Res. Lett. 34: L05817.

Mauger, G.S. and Norris, J.R. (2007). Meteorological bias in satellite estimates of aerosol-cloud relationships. Geophys. Res. Lett. 34: L16824.

Meyer, K., Platnick, S., Oreopoulos, L. and Lee, D. (2013). Estimating the direct radiative effect of absorbing aerosols overlying marine boundary layer clouds in the southeast Atlantic using MODIS and CALIOP. J. Geophys. Res. 118: 4801-4815.
Meyer, K., Platnick, S. and Zhang, Z. (2015). Simultaneously inferring above-cloud absorbing aerosol optical thickness and underlying liquid phase cloud optical and microphysical properties using MODIS. $J$. Geophys. Res. 120: 5524-5547.

Nilsson, E.D., Rannik, Ü., Swietlicki, E., Leck, C., Aalto, P.P., Zhou, J. and Norman, M. (2001). Turbulent aerosol fluxes over the Arctic Ocean 2. Wind driven sources from the sea. J. Geophys. Res. 106: 32139-32154.

Oreopoulos, L., Cho, N., Lee, D. and Kato, S. (2016). Radiative effects of global MODIS cloud regimes. $J$. Geophys. Res. 121: 2299-2317.

Partanen, A.I., Laakso, A., Schmidt, A., Kokkola, H., Kuokkanen, T., Pietikainen, J.P., Petzold, V.M., Hasselbach, A., Lauer, J.P., Baumann, R., Franke, K., Gurk, C., Schlager, H. and Weingartner, E. (2008). Experimental studies on particle emissions from cruising ship, their characteristic properties, transformation and atmospheric lifetime in the marine boundary layer. Atmos. Chem. Phys. 8: 2387-2403.

Petzold, A., Weingartner, E., Hasselbach, I., Lauer, P., Kurok, C. and Fleischer, F. (2010). Physical properties, chemical composition, and cloud forming potential of particulate emissions from a marine diesel engine at various load conditions. Environ. Sci. Technol. 44: 3800-3805.

Radke, L.F., Coakley, J.A. and King, M.D. (1989). Direct and remote sensing observations of the effects of ships on clouds. Science 246: 1146-1149.

Remer, L.A., Kaufman, Y.J., Tanre, D., Mattoo, S., Chu, D.A., Martins, J.V., Li, R.R., Ichoku, C., Levy, R.C., Kleidman, R.G., Eck, T.F., Vermote, E. and Holben, B.N. (2005). The MODIS aerosol algorithm, products, and validation. J. Atmos. Sci. 62: 947-973.

Rosenfeld, D. (2000). Suppression of rain and snow by urban and industrial air pollution. Science 287: 17931796.

Rosenfeld, D., Lahav, R., Khain, A. and Pinsky, M. (2002). The role of sea spray in cleansing air pollution over ocean via cloud processes. Science 297: 1667-1670.

Rosenfeld, D. (2008). Flood or drought: How do aerosols affect precipitation. Science 321: 1309-1313.

Russell, L.M., Sorooshian, A., Seinfeld, J.H., Albrecht, B.A., Nenes, A., Ahlm, L., Chen, Y.C., Coggon, M., Craven, J.S., Flagan, R.C., Frossard, A.A., Jonsson, H., Jung, E., Lin, J.J., Metcalf, A.R., Modini, R., Mülmenstädt, J., Roberts, G., Shingler, T., Song, S., Wang, Z. and Wonaschütz, A. (2013). Eastern pacific emitted aerosol cloud experiment. Bull. Am. Meteorol. Soc. 94: 709729.

Saxe, H. and Larsen, T. (2004). Air pollution from ships in three Danish ports. Atmos. Environ. 38, 4057-4067.

Shen, X., Bilal, M., Qiu, Z, Sun, D., Wang, S. and Zhu, W. (2019). Long-term spatiotemporal variations of aerosol optical depth over Yellow and Bohai Sea. Environ. Sci. Pollut. Res. Int. 26: 7969-7979.

Small, J.D., Jiang, J.H., Su, H. and Zhai, C. (2011). Relationship between aerosol and cloud fraction over Australia. Geophys. Res. Lett. 38: L23802. 
Sorooshian, A., Prabhakar, G., Jonsson, H., Woods, R.K., Flagan, R.C. and Seinfeld, J.H. (2015). On the presence of giant particles downwind of ships in the marine boundary layer. Geophys. Res. Lett. 42: 2024-2030.

Stephens, G., Vane, D.G., Boain, R.J., Mace, G.G., Sassen, K., Wang, Z., Illingworth, A.J., O'Connor, E.J., Rossow, W.B., Durden, S.L., Miller, S.D., Austin, R.T., Benedetti, A. and Mitrescu, C. (2002). The CloudSat mission and the A-train: A new dimension of spacebased observations of clouds and precipitation. Bull. Am. Meteorol. Soc. 83: 1771-1790.

Stevens, B. and Feingold, G. (2009). Untangling aerosol effects on clouds and precipitation in a buffered system. Nature 461: 607-613.

Tan, X.L. (2017). The port industry development $t$ rend of global and the selection to the port industry in China for development model in future. Mar. Eco. China 2 (in Chinese)

Tang, J., Wang, P., Mickley, L. J., Xia, X., Liao, H., Yue, X., Sun, L. and Xia, J. (2014). Positive relationship between liquid cloud droplet effective radius and aerosol optical depth over Eastern China from satellite data. Atmos. Environ. 84: 244-253.

Ten Hoeve, J.E., Remer, L.A. and Jacobson, M.Z. (2011). Microphysical and radiative effects of aerosols on warm clouds during the Amazon biomass burning season as observed by MODIS: impacts of water vapor and land cover. Atmos. Chem. Phys. 11: 3021-3036.

Twohy, C.H., Coakley Jr., J.A. and Tahnk, W.R. (2009). Effect of changes in relative humidity on aerosol scattering near clouds. J. Geophys. Res. 114: D05205.

Twomey, S. (1974). Pollution and the planetary albedo. Atmos. Environ. 41: 120-125.

Twomey, S. (1977). The influence of pollution on the shortwave albedo of clouds. J. Atmos. Sci. 34: 11491152.

Várnai, T. and Marshak, A. (2009). MODIS observations of enhanced clear sky reflectance near clouds. Geophys. Res. Lett. 36: L06807.

Wang, F., Guo, J., Zhang, J., Wu, Y., Zhang, X., Deng, M. and Li, X. (2014a). Satellite observed aerosol-induced variability in warm cloud properties under different meteorological conditions over eastern China. Atmos. Environ. 84: 122-132.

Wang, R. and Zhao, H. (2016). Big data technology development trend and DENGTA application platform. ZTE Tech. J. 22: 57-61. (in Chinese)

Wang, Z., Vane, D., Stephens, G. and Reinke, D. (2013). CloudSat Project: Level 2 combined radar and lidar cloud scenario classification product process description and interface control document. California Institute of Technology, Calif.

Wang, Z., Sorooshian, A., Prabhakar, G., Coggon, M.M. and Jonsson, H.H. (2014b). Impact of emissions from shipping, land, and the ocean on stratocumulus cloud water elemental composition during the 2011 E-PEACE field campaign. Atmos. Environ. 89: 570-580.

Winker, D.M., Pelon, J.R. and McCormick, M.P. (2003). Calipso mission: Spaceborne lidar for observation of aerosols and clouds. Proc. SPIE 4893, Lidar Remote Sensing for Industry and Environment Monitoring III. 4893.

Wu, G. (2016). Open innovation of big data. ZTE Tech. J. 22: 2-6. (in Chinese)

Wu, Y.F., Zhang, R.J., Tian, P., Tao, J., Hsu, S.C., Yan, P., Wang, Q.Y., Cao, J.J., Zhang, X.L. and Xia, X.A. (2016). Effect of ambient humidity on the light absorption amplification of black carbon in Beijing during January 2013. Atmos. Environ. 124: 217-223.

Xin, J.Y., Zhang, Q., Wang, L.L., Gong, C.S., Wang, Y.S., Liu, Z.R. and Gao, W.K. (2014). The empirical relationship between the $\mathrm{PM}_{2.5}$ concentration and aerosol optical depth over the background of north China from 2009 to 2011. Atmos. Res. 138: 179-188.

Yuan, T., Li, Z., Zhang, R. and Fan, J. (2008). Increase of cloud droplet size with aerosol optical depth: An observation and modeling study. J. Geophys. Res. 113: D04201.

Received for review, December 3, 2018 Revised, March 11, 2019 Accepted, June 17, 2019 